\title{
Non-Small Cell Carcinoma
}

National Cancer Institute

\section{Source}

National Cancer Institute. Non-Small Cell Carcinoma. NCI Thesaurus. Code C65151.

A malignant epithelial neoplasm characterized by the absence of neoplastic small epithelial cells. A representative example is the lung non-small cell carcinoma. 